УДК: 65.011.3:06.047

JEL Classifications: M 42

Н. І. ДОРОШ,

доктор економічних наук,

професор кафедри обліку та аудиту,

Киівський національний університет імені Тараса Шевченка

\title{
Оцінювання ризиків при проведенні аудиту
}

У статті розкрито сутність підприємницького ризику та методи управління ризиками суб'єкта господарювання. Висвітлено вплив ризиків на достовірність фінансової звітності. Підкреслено взаємозалежність між вказаними ризиками та ризиком взяття зобов 'язань з аудиту й аудиторським ризиком. Визначено чинники, які впливають на аудиторське рішення про прийняття нового або продовження обслуговування вже існуючого клієнта.

Ключові слова: підприємницький ризик, аудиторський ризик, управління ризиками, планування аудиту, зобов 'язання з аудиту, чесність управлінського персоналу, суттєві викривлення фінансової звітності.

Постановка проблеми. Сучасні тенденції розвитку економіки країн світу, прояви кризових явищ глобального характеру, швидкі зміни умов діяльності суб'єктів господарювання призвели до посилення уваги науковців та практиків до ризиків діяльності підприємств та відповідного зміщення акценту на здійснення зовнішнього та внутрішнього аудиту, орієнтованого на ризики.

Більшість користувачів фінансових звітів сподіваються, що аудитор виявить практично всі помилки та порушення, які матимуть суттєвий вплив на фінансову звітність, незалежно від того, як вони відбулися або як вони були приховані. Розрив очікувань вказує на невідповідність між уявленнями користувачів та аудиторів про відповідальність за виявлення викривлень фінансової звітності. Підвищуючи ймовірність виявлення, ефективний аналіз ризику аудиту дає можливість аудитору краще відповідати очікуванням користувачів.

Якщо аудиторські ресурси зосереджуються в сегментах підвищеного ризику, імовірність невиявлених помилок зменшується. Отже, як аналіз ризику наявності суттєвих викривлень, так і аналіз ризику контролю впливають на характер, час та обсяг основних перевірок.

Аналіз останніх досліджень і публікацій. Вагомий внесок у розвиток теоретичних основ та проблематики аудиту зробили: С. Бардаш, В. Головач, Н. Дорош, Т. Каменська, В. Пантелеєв, Н. Проскуріна, О. Редько, В. Рудницький, Л. Сухарева, Н. Шалімова, М. Шигун та інші.

Аналіз наукової літератури та спеціальних джерел показує спрямованість досліджень на визначення сутності аудиту та його видів, удосконалення методології аудиту, зокрема процедур отримання аудиторських доказів [7] та використання міжнародних стандартів аудиту [8], застосування вибіркових досліджень в загальній системі аудиту [10].

Зростання конкурентного та ризикового середовища економіки країни обумовлює необхідність посилення управління ризиками діяльності підприємства. Аудит, оснований на ризику, є найбільш визначальним та суттєвим в розвитку історії аудиту. Значна увага у цьому зв'язку приділяється розкриттю сутності та методів оцінювання аудиторського ризику [4; 5]. Особливо важливе значення в управлінні та контролі ризиків відіграє внутрішній аудит, якому присвячується дедалі більша кількість наукових праць $[2 ; 3 ; 9 ; 11 ; 13]$.

Водночас потребують подальшого розвитку теоретичні та методологічні питання оцінювання та управління ризиками суб'єкта господарювання, а також їх впливу на ризик прийняття зобов'язань 3 аудиту та аудиторський ризик.

(C) H. I. Дорош, 2017 
Основною метою статті $є$ розкриття взаємозв'язку ризиків, які супроводжують проведення аудиту, з метою мінімізації аудиторського ризику формування адекватного аудиторського висновку на основі ризиків фінансової звітності підприємства та ефективності внутрішнього контролю.

Виклад основного матеріалу. Підприємства ризикують щодня впродовж всієї своєї діяльності. Ризик є невід'ємною частиною ділової активності, адже завжди існує ризик того, що нова продукція зазнає невдачі, непередбачувані економічні події відбудуться, або бажаний результат буде малоймовірним. В сучасних умовах економічної нестабільності зростає необхідність управління підприємницьким ризиком. Правильна оцінка ситуації і вибір методу управління ризиками є важливими інструментами досягнення економічних цілей підприємства. Важливим є вміння правильно і своєчасно виявляти підприємницькі ризики і приймати відповідні рішення в рамках розробленої підприємством політики управління ризиками з врахуванням економічної тактики і стратегії підприємства.

Складовою менеджменту підприємств є політика управління ризигом. Політика управління ризитом - сукупність форм, методів, придамів і способів управління ризиюм, метою яких є зниження загрози прийняття неадекватних рішень та зменшення потенційно негативних тслідків.

Ризик-менеджмент - це комплекс заходів, спрямованих на мінімізацію можливих збитків, які може понести бізнес у зв'язку з настанням негативних подій [1].

$€$ кілька способів, якими працівники підприємства можуть управляти ризиками, щоб звести їх до прийнятного рівня: уникнення ризиків, наприклад, не розпочинати бізнес $з$ продажу інноваційних продуктів або закрити підприємство з виробництва небезпечних хімічних речовин. Цей процес відомий як "припинення дії"; передача ризиків, іiї найкращим прикладом служить страхування; прийняття ризиків, не плануючи при цьому ніяких непередбачених обставин, витрат; прийняття ризиків з одночасним плануванням їх імовірності та непередбачуваних витрат; запровадження таких процесів та систем, які дозволяють зменшити наслідки або/та ймовірність ризику. Ці процеси зазвичай називають "контроль, управління", і вони включають все: від чіткої стратегії підприємства до встановлення пожежної сигналізації [15, с. 3].

Отже, цілі підприємства перебувають під загрозою ризиків і потребують відповідних дій для ix , щоб їх уникнути, прийняти, передати або зменшити чи мінімізувати. Методика управління ризиками на підприємстві впливає і на його фінансову стійкість, і на аудиторські процедури, які використовуються.

Аудиторові необхідно оцінити ризики суб'єкта господарювання, а також те, наскільки ефективно система управління визначає їх та управляє ними. Результати аналізу ризиків підприємства безпосередньо впливають на кількість та напрями аудиторських робіт, які необхідно виконати. При здійсненні планування аудиторської перевірки необхідно чітко сформулювати унікальні ризики підприємства-клієнта, пов'язати ці ризики з певними сальдо рахунків і відповідними твердженнями у фінансових звітах, а також визначити типи аудиторських процедур, які мають бути виконані з врахуванням впливу ризиків. Без розуміння ризику персонал аудиторської фірми не може виконати свої зобов'язання, особливо щодо клієнтів, які мають високий ризик наявності суттєвих викривлень у фінансовій звітності.

Ризик є поширеним поняттям. Існує багато визначень ризику і підходів для управління ризиками. Поняття ризик можна тлумачити в таких аспектах: ризик як небезпека чи загроза, можливість настання подій з негативними наслідками, реалізації передбачуваної небезпеки; ризик як можливість має у своїй основі концепцію існування взаємозв' язку між ризиком і прибутковістю, чим вище ризик, тим вище потенційний доход; ризик як невизначеність пов'язаний із таким теоретичного поняттям як імовірнісний розподіл можливих результатів (позитивних і негативних).

Ризик - це набір обставин, які заважають (перешкоджають) досягненню цілей. Альтернативним способом визначення ризику може бути імовірність настання ризику та його наслідків. Наприклад, ISO (Міжнародна організація зі стандартизації) визначає ризик як "поєднання (сукупність) вірогідності події та її наслідків" (ISO/ IEC Керівництво 73). Наступне визначення також вимагає наявності цілей. У разі відсутності будь-якої мети ми не маємо жодних ризиків. Це призводить до цікавих 
спостережень: один і той самий набір обставин може бути як сприятливим, так і загрозливим, залежно від нашої мети [15, с. 7].

Доцільно визначити чотири компоненти ризику, які стосуються проведення зовнішнього аудиту:

^ підприємницький ризик - ризик, який впливає на господарські операції і потенційні результати діяльності підприємства;

$\wedge$ ризик фінансової звітності - ризик, який стосується запису, фіксації господарських операцій і відображення інформації у фінансовій звітності підприємства;

$\wedge$ ризик взяття зобов'язань - ризики, які виникають через те, що аудитори пов'язані з певними клієнтами; це, зокрема, втрата репутації, нездатність клієнта сплатити грошові кошти аудиторові або грошові втрати, пов'язані 3 нечесністю менеджерів підприємства або забороною проведення аудиту, певних аудиторських процедур;

$\wedge$ аудиторський ризик - ризик того, що аудитор надасть позитивний аудиторський висновок за умови, що у фінансовій звітності наявні суттєві викривлення.

На рисунку показано взаємозалежність між наведеними ризиками. На найширшому рівні підприємницький ризик і ризик фінансової звітності виникає між замовником аудиту та його середовищем, і ці ризики потім впливають на ризик взяття зобов'язань і аудиторський ризик.

Існує велика кількість чинників, які впливають на підприємницький ризик. Повністю сприятливий або несприятливий економічний клімат може мати величезний вплив на можливість підприємства працювати ефективно і з вигодою. Економічні спади часто супроводжуються "падінням" підприємств, які здавалися успішними. Технічний прогрес також є ризиком для багатьох підприємств. Дії конкурентів, такі як зниження цін або поява нових товарів, також впливають на підприємницький ризик. За умов фінансової кризи складність фінансових інструментів і транзакцій може збільшити підприємницький ризик і, відповідно, ризик фінансової звітності. Нарешті, географічні місця розташування постачальників можуть також впливати на підприємницький ризик.

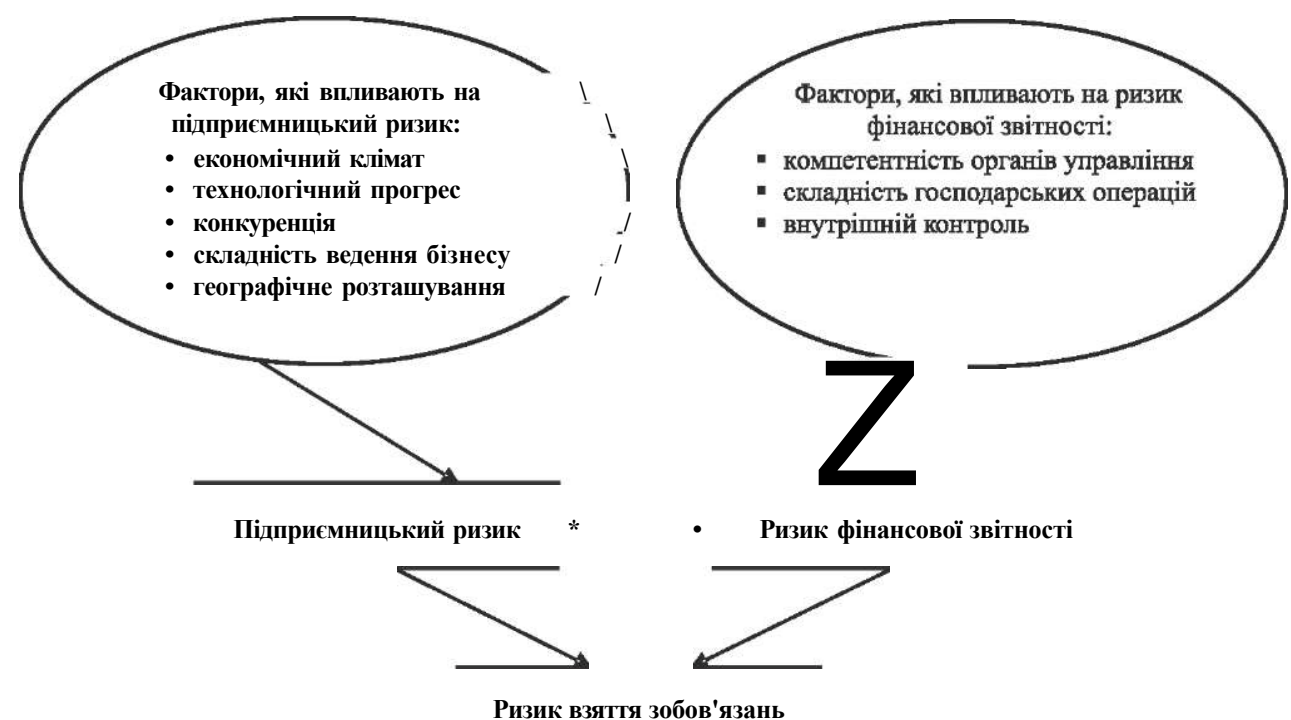

Аудиторський ризик

Рис. Взаємозв'язок між елементами ризиків, які впливають на аудит Джерело: побудовано автором за [14, с. 126] 
Що стосується ризиків фінансової звітності, то необхідно дослідити всі статті балансу підприємства, які є суб'єктивними та грунтуються на професійному судженні. Існують судження, пов'язані з такими проблемами як невідповідність активів критеріям визнання, справедлива вартість активів, гарантії, повернення, пенсії і оцінки відповідно до строку корисного використання активів. Через ці оцінки ризик фінансової звітності знаходиться під впливом таких чинників як компетентність та єдність системи управління, мотивація до викривлень фінансової звітності. У період економічного спаду модель бухгалтерського обліку потребує більшого обсягу ринкової інформації для її включення у фінансові звіти. Більше підприємств будуть оцінювати основні засоби та гудвіл за зменшенням корисності; дебіторську заборгованість за поверненістю; запаси за чистою реалізаційною вартістю; значні фінансові інструменти за поточною ринковою вартістю; зобов'язання, такі як гарантії або інші нарахування, за потенційним заниженням.

Крім того, складність певних господарських операцій може впливати на ризик фінансової звітності. Нарешті, внутрішній контроль підприємства може впливати на ризик фінансової звітності шляхом попередження або виявлення помилок та навмисних викривлень.

Підприємницький ризик і ризик фінансової звітності можуть впливати один на одного; наприклад, підприємство діє в умовах значної конкуренції і має невисокі фінансові результати, може бути мотивованим обійти слабку систему внутрішнього контролю або використати у своїх інтересах складні фінансові інструменти для досягнення бажаних результатів фінансової звітності, навіть якщо фінансова звітність не відображає реальний стан підприємства. Крім того, і підприємницький ризик, і ризик фінансової звітності впливають на ризик взяття зобов'язань.

Наприклад, якщо клієнт оголошує про банкрутство або несе надзвичайно великі втрати, то цілком імовірно, що аудиторській фірмі можуть висунути позов. Аудиторські фірми виявили, зв'язок із компаніями з невисокою чесністю, такими як Lehman Brothers, WorldCom, Parmalat, AIG, Enron, створює ризики, які можуть зруйнувати аудиторську фірму, привести до витрат на судочинство і зниження репутації, або збільшити вартість проведення аудиту [14, с. 127].

Відповідно до МСА 320 "Суттєвість при плануванні та проведенні аудиту" аудиторський ризик полягає в тому, що аудитор надасть невідповідний аудиторський висновок, якщо фінансова звітність є суттєво викривленою. Аудиторський ризик $є$ функцією ризиків суттєвого викривлення та ризику не виявлення [6, с. 348]. Аудитор може управляти аудиторським ризиком двома різними способами:

^ уникати аудиторського ризику, не приймаючи певні підприємства як клієнтів і відтак знижуючи ризик взяття зобов'язань до нуля;

^ встановлювати аудиторський ризик на такому рівні, на якому можна зменшити ймовірність того, що аудитор не виявить суттєві викривлення.

Управляючи аудиторським ризиком, аудитор має розуміти, що аудиторський ризик не може бути усунений. Проте він може бути зменшений шляхом виконання більшої кількості аудиторських процедур,призначених для певних сфер, де ризик фінансової звітності є високим. Разом з тим, виконання більшої кількості робіт підвищує вартість аудиту, що може призвести до непорозумінь з органами управління клієнта. Наприклад, якщо інша, альтернативна аудиторська фірма зробила б аудит клієнта за меншу вартість, тоді аудитор має вибір: переконати замовника аудиту, що зниження аудиторського ризику є взаємовигідним для клієнта і для аудитора; взяти на себе більш високий аудиторський ризик, скоротивши кількість процедур аудиту і знизивши вартість аудиторських робіт; зменшити доход, отриманий за той самий обсяг виконаних робіт; відмовитись від клієнта. Якщо підприємницький ризик високий, аудитор може вирішити не розпочинати аудит клієнта, оскільки ризик взяття зобов'язань $€$ занадто високим.

Можливо, найважливішим рішенням аудиту, яке приймається при кожному аудиторському завданні, є визначення того, чи приймати клієнта для обслуговування i чи продовжувати співпрацювати 3 ним. Більшість аудиторських фірм розробляють формалізовані процедури, за допомогою яких розглядаються чинники залучення нових клієнтів та збереження вже існуючих. Особливо це стосується прийняття на обслуго- 
вування потенційних високо ризикованих клієнтів. Існує багато чинників, що впливають на аудиторське рішення про прийняття замовника аудиту та продовження його обслуговування: чесність управлінського персоналу; незалежність і компетентність органів управління і ради директорів; якість процесу управління ризиками і засобів управління; вимоги до звітності, включаючи нормативні вимоги; участь ключових зацікавлених сторін; існування угод з пов'язаними сторонами; фінансова стабільність підприємства.

Рішення про прийняття або збереження клієнта має включати інтерв'ю 3 попередніми аудиторами для отримання знань про їх досвід роботи 3 підприємством. Якщо аудитор клієнта змінюється, новий аудитор має зустрітися 3 попереднім аудитором, щоб дізнатись у нього про причини заміни аудитора, включаючи інформацію щодо суперечок з управлінським персоналом. Перш за все він має спитати попереднього аудитора, чи були в нього розбіжності з клієнтом стосовно застосування аудиторських процедур або принципів обліку, які призвели до заміни попередньої аудиторської фірми. Через конфіденційність інформації аудитору необхідно мати дозвіл клієнта на зустріч із попереднім аудитором. Відмова в дозволі на такий доступ - це чіткий попереджувальний сигнал для аудитора.

Bci SEC- зареєстровані компанії зобов'язані повідомляти, за формою 8-K, про зміну аудиторської фірми та її причини впродовж чотирьох робочих днів. Регістрант має, зокрема, прокоментувати, чи мала компанія які-небудь значні розбіжності зі своїми аудиторами щодо принципів обліку, аудиторських процедур або інших питань фінансової звітності, і має вказати назву нової аудиторської фірми. Попередня аудиторська фірма повинна спілкуватися з SEC, повідомивши, чи погоджується вона з інформацією, яку повідомив клієнт [14, с. 129 ].

Найбільш важливим чинником для аудитора можна вважати чесність управлінського персоналу. Аудитор має зрозуміти і оцінити чесність управлінського персоналу та економічні стимули, які впливають на управління. Існує велика кількість потенційних джерел, з яких аудитор може отримати інформацію про чесність управлінського персоналу: це попередні аудитори, досвід аудиту попереднього року і незалежні джерела інформації (таблиця).

Таблиия

Джерела інформації стосовно чесності управлінського персоналу

\begin{tabular}{|l|l|}
\hline \multicolumn{1}{|c|}{ Джерела інформації } & \multicolumn{1}{|c|}{ Склад та умови надання інформації } \\
\hline Попередній аудитор & $\begin{array}{l}\text { Зобов'язаний надати відповідь аудиторові, якщо } \\
\text { необхідна інформація не знаходиться під контролем } \\
\text { суду або якщо клієнт не підтвердить конфіденційність } \\
\text { інформації. }\end{array}$ \\
\hline $\begin{array}{l}\text { Інші професіонали в ділових } \\
\text { колах }\end{array}$ & $\begin{array}{l}\text { Наприклад, юристи і банкіри, з якими аудитор зазвичай } \\
\text { будує хороші робочі стосунки і про кого аудитор наво- } \\
\text { дить довідки, які є частиною процесу ознайомлення з } \\
\text { бізнесом клієнта. }\end{array}$ \\
\hline $\begin{array}{l}\text { Інші аудитори аудиторської } \\
\text { фірми }\end{array}$ & $\begin{array}{l}\text { Можливо мали справу з поточними органами управлін- } \\
\text { ня клієнта при виконанні інших завдань з аудиту чи з } \\
\text { іншими клієнтами. }\end{array}$ \\
\hline $\begin{array}{l}\text { ЗМІ і пошук в мережі Інтер- } \\
\text { нет }\end{array}$ & $\begin{array}{l}\text { Інформація про підприємство та його органи управ- } \\
\text { ління може бути доступною у різних журналах та в } \\
\text { мережі Інтернет. }\end{array}$ \\
\hline Громадські бази даних & $\begin{array}{l}\text { Громадські бази даних можуть містити, наприклад, } \\
\text { інформацію про судові розгляди проти підприємства } \\
\text { або головних членів управління. }\end{array}$ \\
\hline $\begin{array}{l}\text { Попередні інтерв'ю з органа- } \\
\text { ми управління }\end{array}$ & $\begin{array}{l}\text { Можуть бути корисними для розуміння даних іпричин } \\
\text { обороту ключових позицій, а також при аналізі "від- } \\
\text { вертості" управлінського персоналу стосовно важливих } \\
\text { проблем підприємства, які впливають на аудит. }\end{array}$ \\
\hline
\end{tabular}


Продовження табл.

\begin{tabular}{|l|l|}
\hline \multicolumn{1}{|c|}{ Джерела інформації } & \multicolumn{1}{|c|}{ Склад та умови надання інформації } \\
\hline Члени аудиторського комітету & $\begin{array}{l}\text { Можливо були залучені до спорів між попередніми } \\
\text { аудиторами і управлінським персоналом і можуть за- } \\
\text { безпечити додаткове розуміння. }\end{array}$ \\
\hline Запити органів контролю & $\begin{array}{l}\text { У аудитора може бути причина навести довідки про } \\
\text { певні дії органів контролю та історії регуляторних за- } \\
\text { ходів стосовно підприємства і його управління. }\end{array}$ \\
\hline $\begin{array}{l}\text { Приватні фірми з розсліду- } \\
\text { вання }\end{array}$ & $\begin{array}{l}\text { Такі фірми використовуються, коли аудитор дізнається } \\
\text { про проблеми, стосовно яких необхідно робити по- } \\
\text { дальший запит про чесність управлінського персоналу } \\
\text { або його участь у потенційній незаконній діяльності. }\end{array}$ \\
\hline
\end{tabular}

Джерело: складено автором

Невідповідні процеси управління ризиками є достатньою причиною для неприйняття потенційного замовника аудиту. Аудитор має оцінити зобов'язання органів управління реалізувати ефективну систему управління ризиками. Налагодження ефективної системи управління ризиками та внутрішнього контролю свідчить про спрямованість підприємства на довгострокові стратегії. Підприємство без таких зобов'язань розглядається як таке, що посилює ризик взяття зобов'язань. Зрозуміло, що ризик може бути компенсований шляхом виконання додаткових аудиторських процедур. Проте дослідження показують, що аудитори не можуть завжди виконувати достатню кількість аудиторських процедур для компенсації недоліків системи внутрішнього контролю.

MCA 315 "Ідентифікація та оцінювання ризиків суттєвого викривлення через розуміння суб'єкта господарювання та його середовища" надає резюме потенційних ризиків суб'єкта господарювання, які можуть бути пов'язані з суттєвими викривленнями у його фінансовій звітності. Існування більше одного з таких ризикових чинників не обов'язково означає наявність суттєвого викривлення, але дійсно вказує на те, що аудиторові необхідно буде ретельно дослідити таку можливість, що очевидно призводить до зростання кількості аудиторських робіт. Наведені ризики пов'язані 3 широким спектром і господарських операцій, і рішень фінансової звітності, іноді їх важко визначити, оскільки вони узагальнені за своєю сутністю. Багато підприємств можуть мати ці ризики, але не матимуть суттєвих викривлень фінансової звітності, що не дає можливості аудиторам визначити, коли ризиковий чинник дійсно призведе до викривленя інформації у конкретного клієнта.

У додатку до МСА 315 "Ідентифікація та оцінювання ризиків суттєвого викривлення через розуміння суб'єкта господарювання та його середовища" [6, с. 342, 343] наводяться такі умови та події, що можуть вказувати на ризики суттєвого викривлення: діяльність в економічно нестабільних регіонах, наприклад у країнах зі значною девальвацією грошової одиниці або дуже високим рівнем інфляції; діяльність, чутлива до нестабільних ринків, наприклад торгівля ф'ючерсами; діяльність, яка значною мірою підлягає заходам комплексного регулювання; припущення щодо безперервності діяльності та питання ліквідності, включаючи втрату значних клієнтів; обмеження доступності капіталу та кредиту; зміни в галузі, в якій працює суб'єкт господарювання; зміни в логістичному ланцюзі; розроблення або пропонування нових продуктів чи послуг, або започаткування нових видів діяльності; розширення у нові регіони; зміни у суб'єкта господарювання, такі як великі придбання, чи реорганізації або інші незвичні події; ймовірний продаж суб'єктів господарювання або сегментів бізнесу; існування складних альянсів і спільних підприємств; використання позабалансового фінансування підприємств спеціального призначення та інших складних фінансових схем; значні операції з пов'язаними сторонами; недостатня кількість персоналу з відповідними навичками бухгалтерського обліку та фінансового звітування; зміни у складі ключового персоналу, включаючи звільнення основних керівників; недоліки у внутрішньому контролі, особливо ті, на які не реагує управлінський персонал; невідповідність між IT-стратегією суб'єкта господарювання та його бізнес-стратегією. 
Н. И. ДОРОШ,

доктор экономических наук, профессор, профессор кафедры учета и аудита, Киевский национальный университет имени Тараса Шевченко

\section{Оценивание рисков при проведении аудита}

В статье раскрыты сущность предпринимательского риска и методы управления рисками субъекта хозяйствования. Раскрыто влияние рисков на достоверность финансовой отчетности. Подчеркнута взаимозависимость между указанными рисками и риском взятия обязательств по аудиту и аудиторским риском. Определень факторь, влияющие на аудиторское решение о принятии нового или продолжении обслуживания уже имеющегося клиента.

Ключевые слова: предпринимательскийриск, аудиторский риск, управление рисками, планирование аудита, обязательство по аудиту, честность управленческого персонала, существенные искажения финансовой отчетности.

N. I. DOROSH,

Dsc (Economics), Professor, Professor of Accounting and Audit Department, Kyiv National Taras Shevchenko University

\section{Risk Assessment in Audit}

The article's objective is to demonstrate the causality of risks involved in the audit, in order to minimize the audit risk associated with formulating the adequate audit conclusion based on the risks of the company's financial reporting and the effectiveness of company's internal control.

The meaning of entrepreneurial risk and risk management methods at company level are discussed, with emphasizing the impact of risks on the reliability offinancial reporting. Four components of the risk involved in external audit are outlined and discussed: entrepreneurial risk, risk offinancial reporting, risk of taking obligations, risk of audit. The causality between risk components having impact on audit is illustrated. The essence and methods of risk management in audit are analyzed. It is demonstrated that the issue of whether or not a client be accepted for audit service and whether or not the audit-based cooperation with it be prolonged constitutes a primary decision with respect to each audit. Factors behind the auditor's decision to accept a new client or continue to work with the previous one are highlighted. It is emphasized that the honesty of management personnel has the foremost importance for an auditor; sources of information about the honesty of management personnel are shown.

Keywords: entrepreneurial risk, audit risk, risk management, planning of audit, obligation on audit, honesty of management personnel, essential distortions of financial reporting.

Посилання на статтю:

Дорош Н. І. Оцінювання ризиків при проведенні аудиту // Науковий вісник Національної академії статистики, обліку та аудиту: зб. наук. пр.. 2017. №4. С. 40-47. 